\title{
Extraction of Natural Dye from Ixora coccinea (Linn.) Flowers for Cotton Fabric Colouration
}

\author{
Monali U. Ghurde ${ }^{1}$, M. M. Padwad ${ }^{2}$, V. R. Deshmukh ${ }^{3}$, S. N. Malode ${ }^{4}$ \\ ${ }^{1,2,3}$ Department of Botany, Vidya Bharati Mahavidyalaya, Amravati, Maharashtra, India \\ ${ }^{4}$ P.G. Department of Botany, Govt. Vidarbha Institute of Science \& Humanities, Amravati
}

\begin{abstract}
In the present study, experiments were carried out to use an extract isolated from floral petals of Ixora coccinea (Linn.) with aqueous and methanol as a natural dye. The dye potential of the extract was evaluated by dyeing on cotton fabrics under the normal dyeing conditions and tested for their colour fastness to washing properties. The pigments were isolated from fresh flowers of Ixora coccinea (Linn.) and studied in order to understand the process of dying during cotton cloth coloration using different mordants such as Alum, Copper sulphate, ferrous sulphate and Stannous chloride. The various shades were obtained by Ixora coccinea (Linn.)Flower on cotton fabrics. Aqueous extract without mordant (Control) exhibits Windsor cream 6860 shade that is matched with Walnut cream 8778, Riverbed Sand 8462, Dark ash 8776 and Pampered Pink 8696 shades obtained in Alum (5\%), Copper sulphate (2\%), Ferrous sulphate (2\%) and Stannous chloride (2\%) respectively. Shades generated in mordants were all unique and different than control. The results revealed that the Methanolic extract of Ixora coccinea (Linn.) flower extracted more pigments and exhibits dark shades on cotton fabric as compared to aqueous. Methanol Control exhibits bright Rose petal 0208 shade that is matched with shades obtained in respective mordants i.e. Sparrow feather 8659, Quarry stone 8658, Digital grey 8312 and Dash of purple respectively. The shade obtained is matched with Asian-paint color shades card which makes it easier for the user to communicate about the shade without actually sending sample. The changes in shades of some of the colors have been noticed after washing with soap. The Spectroscopic analysis of dye color have also been made for identification of certain bonding/functional groups present in the dye extract, the technique can used to identify the interaction of the dye with mordents. Secondly, mordanting with the different metal salts exhibited variation in color hue because of their ability to form coordination complexes with the dye molecules, which resulted in different shades to cotton fabrics. These findings revealed that the extract of floral petals of Ixora coccinea (Linn). can be used for cotton fabric coloration.
\end{abstract}

Keywords: Ixora coccinea, Natural dye, Mordents, Asian paint charts, Cotton fabric.

\section{Introduction}

Nature expresses itself in a wide spectrum of colours all around us. Dyeing is an ancient art and it was practicised during the Bronze Age in Europe. Primitive dyeing techniques were included sticking plants to fabric or rubbing crush pigments into cloth. The method became more sophisticated over time but presently there $s$ an excessive use of synthetic dyes. The production and application of which release vast amount of waste and unfixed colourants, causing serious health hazards and disturbing the eco-balance of nature. Currently ecological considerations are becoming an important factor in the selection of consumer goods all over the world. Natural dyes are known for their use in the selection of food substrata, leather as well as natural protein fibres like wool, silk and cotton as the major areas of application since prehistoric time. Dyeing is an antiquated art as well as modern science complex. Presently there is an excessive use of synthetic dyes estimated at around 10,000,000 tonns per annum [3], the production and application of which release vast amount of waste and unfixed colorants causing serious health hazard and disturbing eco-balance of nature [4]. Natural dyes are the colours derived from plants and animals or insect matter without any chemical processing [10],[9]. They can offer not only a rich and varied source of dye stuff, but also the possibility of an income through sustainable sale of these dye plants. But the certain problems with the use of natural dyes in the textile dyeing are colour yield, complexity of dyeing process, reproducible results, limited shades and inadequate fastness properties[11[,[13] but these problems can be overcome by using chemicals called mordants. Mordants are the metal salts which produce an affinity between dye and fabri [15[,[12]. In general, it has been observed from the literature that the identification of natural dyes in textiles involves selective extraction of dyes and comparison of each dye by various characterization techniques, viz. UV-Visible and IR spectroscopy, TLC, HPLC, ecotoxicity (LD-50) and bio-assay, including methods of identification of vegetable dyes on cellulose fibres, animal fibres and man-made fibres. UV visible spectra of any colourant/dye show its peaks at predominating wavelength, indicating main hue. For natural dyes, the spectra specially indicate different peaks for mixed colourants available in their extract in both UV and visible region. UV/ Visible spectroscopic studies of different natural dyes were carried out [1] using different solvents for extraction.

Ixora coccinea Linn. (Rubiaceae) is also known as Jungle Geranium or Flame of the Woods or Vetchi in Ayurveda. It is a common flowering shrub native to Asia. The plant is a dense, much branched evergreen shrub, commonly 4-6 ft (1.2$2 \mathrm{~m})$ in height, but capable of reaching up to $12 \mathrm{ft}(3.6 \mathrm{~m})$. Leaves are sessile to short-petiolate, glossy, leathery, oblong and are about $10 \mathrm{~cm}$ long, with entire margins and are arranged in opposite pairs or whorled on the stem, stipules basally sheathing, Flowers small, sessile, tubular and are 


\section{International Journal of Science and Research (IJSR) \\ ISSN (Online): 2319-7064 \\ Index Copernicus Value (2013): 6.14 | Impact Factor (2014): 5.611}

arranged in dense rounded clusters, calyx lobes short, triangular, persistent,corolla tube usually 1-1.5 inches long, lobes lanceolate to ovate, acute or sometimes obtuse, Fruit fleshy and reddish black. The plant is traditionally used as hepatoprotective, Chemoprotective, antimicrobial, antioxidant, anti-mitotic and anti-inflammatory activities [14].

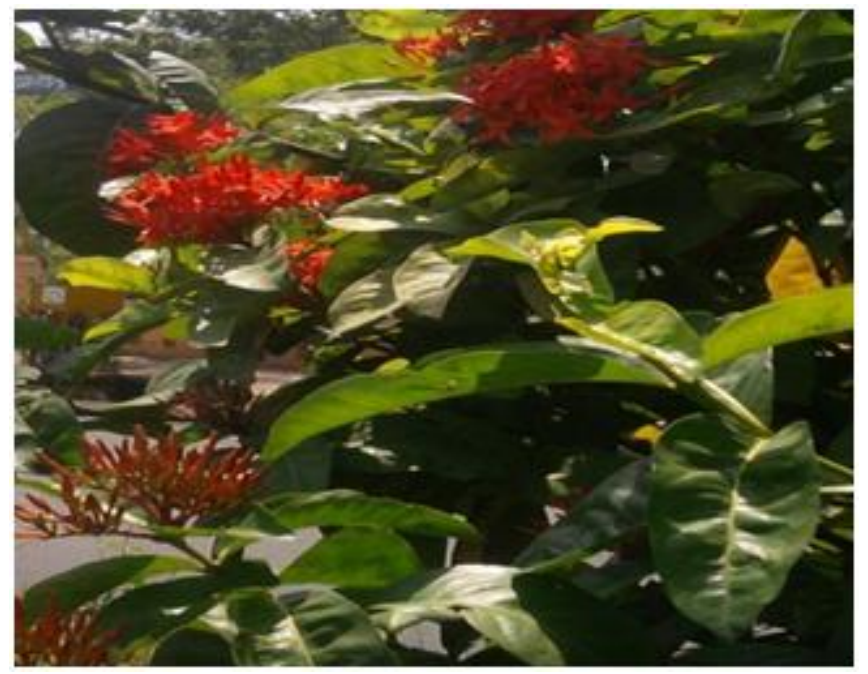

The present work has tried to document the methodology of dye extraction from Ixora coccinea (Linn.) flowers, also to study the interaction of dye with different mordants for variation in shades on cotton fabric. The shade obtained is matched to the Asian paint colour shade which makes it easier for the user to communicate about the shade without actually sending sample. Second part of study is spectroscopic analysis of dye colour, for identification of certain bonding elements/functional groups present in the dye extract; the technique can used to quantitatively indentify the presence of these groups.

\section{Materials and Methods}

\subsection{Materials}

1) Source: A dark red healthy variety of Ixora coccinea (Linn.) flowers were collected from the campus of VidyaBharati Mahavidyalaya, Amravati.

2) Substrate: Cotton fabric were obtained from KhadiGramodhogh Amravati and used for dyeing.

3) Chemicals: 5\% Alum, 2\% copper sulphate, 2\% ferrous sulphate, $2 \%$ stannous chloride

\subsection{Methods}

\section{a) Extraction of Dye}

Fresh floral petals of Ixora coccinea (Linn.) were crushed dissolved and boiled in water and methanol at $80^{\circ} \mathrm{C}$ for $2 \mathrm{hrs}$ and were found floral petals to discharge color in methanol very easily than water. Increasing the quantity of floral petals accompanied with the increase in color strength and depth in color [9]. It was observed that, color of the dye extract was dark red. The solution was filtered for immediate use.

\section{b) Pre- treatment (Scouring of cotton):}

Cotton fabric were washed in a solution containing $0.025 \mathrm{~g} / \mathrm{L}$ sodium carbonate $\left(\mathrm{Na}_{2} \mathrm{CO}_{2}\right)$ and $0.06 \mathrm{~g} / \mathrm{L}$ non- ionic detergent solution at $50^{\circ} \mathrm{C}$ for $25 \mathrm{~min}$. keeping the material to liquor ratio $1: 40$. The scoured material was thoroughly washed with tap water and dried at room temp. The scoured material was soaked in clean water for 30 minutes prior to dyeing or mordanting [4],[6].

\section{c) Mordanting}

Accurately weighed scoured cotton fabric cotton samples were treated with different metal salt before dying. The mordant $2 \%$ (owf) was dissolved in water to make liquor ratio 1: 40. The wetted samples were dipped into the mordant solution and then brought to heating. Temperature of the dye bath was raised to $80^{\circ} \mathrm{C}$ over a period of half an hour and left at that temperature for another 30 minutes. The mordant material was then rinsed with water thoroughly squeezed and dried. The cotton fabrics soaked in various mordants are used immediately for dyeing because some mordants are very sensitive to light.

\section{d) Dying}

The mordant cotton fiber was dyed with dye extract. Keeping M: L ratio as 1: 40; however, for cotton dyeing it was used directly. Dying was done by the conventional dyeing method. After dyeing, the dyed material was washed with cold water and dried at room temperature. It was then dipped in brine for dye fixing. After this it was washed with non- ionic detergent and dried under shade.

\section{e) UV- Visible Spectroscopic study}

UV visible spectra of any colorant/dye show its peaks at predominating wavelength, indicating main hue. For the natural dyes, the spectra specially indicate different peaks for mixed colorants available in their extract in both UV and visible region. $190 \mathrm{~nm}$ to $1100 \mathrm{~nm}$ UV-VIS spectroscopic analysis was carried out on UV-VIS Elico-spectrophotometer.

\section{Results and Discussion}

The objectives of this study were to evaluate the light fastness of natural dyes extracted from Ixora coccinea flowers and the effect of some commonly use mordants to fix colour and to obtain different shades on the cotton fabric. The natural dyes present in plants and animals are pigmentary molecules, which impart colour to the materials. These molecules containing aromatic ring structure coupled with a side chain are usually required for resonance and thus to impart colour. There is a correlation of chemical structure with colour, chromogenchromophore with auxochrome [8]. Mordants play very important role in imparting color to the fabric. The mordants used in combination in different ratios gave varying shades. Better color strength results are dependent on the metal salt used [5]. The resistance of a dye or pigment to chemical or photochemical attack is an inherent property of the dye chromophore, but at the same time the auxochrome may also substantially alter the fastness. Wash fastness of dye is influenced by the rate of diffusion

\section{Volume 5 Issue 1, January 2016}




\section{International Journal of Science and Research (IJSR) \\ ISSN (Online): 2319-7064 \\ Index Copernicus Value (2013): 6.14 | Impact Factor (2014): 5.611}

of dye and state of dye inside the fiber. The dye extracted from Ixora flowers exhibits good to excellent wash fastness. Secondly, they have a tendency to aggregate inside the fiber and hence exhibit good wash fastness. Mordants used in the present study also have the effect of insolubilizing the dye, making it color fast. Present study indicated that a changes of some colours in the dyed samples of cotton fabric with different mordents (Plate No. I and II). Natural dyes mostly require a mordant to be fixed onto the fiber. The cotton fabrics were dyed with chemical mordants. It was observed that, the dye uptake was good in pre-mordanting method as shown in photoplate I/II. Various hues of color were obtained from premordanted cotton with alum, copper sulphate, ferrous sulphate and stannous chloride. They have an affinity for the dye and the fiber that forms an insoluble precipitate with the dye in the fiber [4]. Different type of mordants and method of mordanting significantly affect the rate and extent of photo fading.The various shades were obtained by Ixora coccinea (Linn.) flower on cotton fabric. Methanolic extract of Ixora coccinea (Linn.) extracted more pigments as compared to aqueous. Among all the shades, the shades obtained in aqueous and methanolic extract on cotton fabric in control (without mordants) exhibits light shades i.e. Windsor cream 6860 and Rose petal 0208 respectively. Aqueous extract without mordant (Control) exhibits light shades i.e.Windsor cream 6860 that is matched with Walnut cream 8778, Riverbed sand 8462 Dark ash 8776 and Pampered pink 8696 shades were obtained in Alum (5\%), Copper sulphate (2\%), Ferrous sulphate (2\%) and Stannous chloride (2\%) respectively (Photo Plate - I). Shades generated in mordants were all unique and different than control.

Plate 1: Color obtained on cotton cloth by using Different Mordants with aqueous dye extract after wash

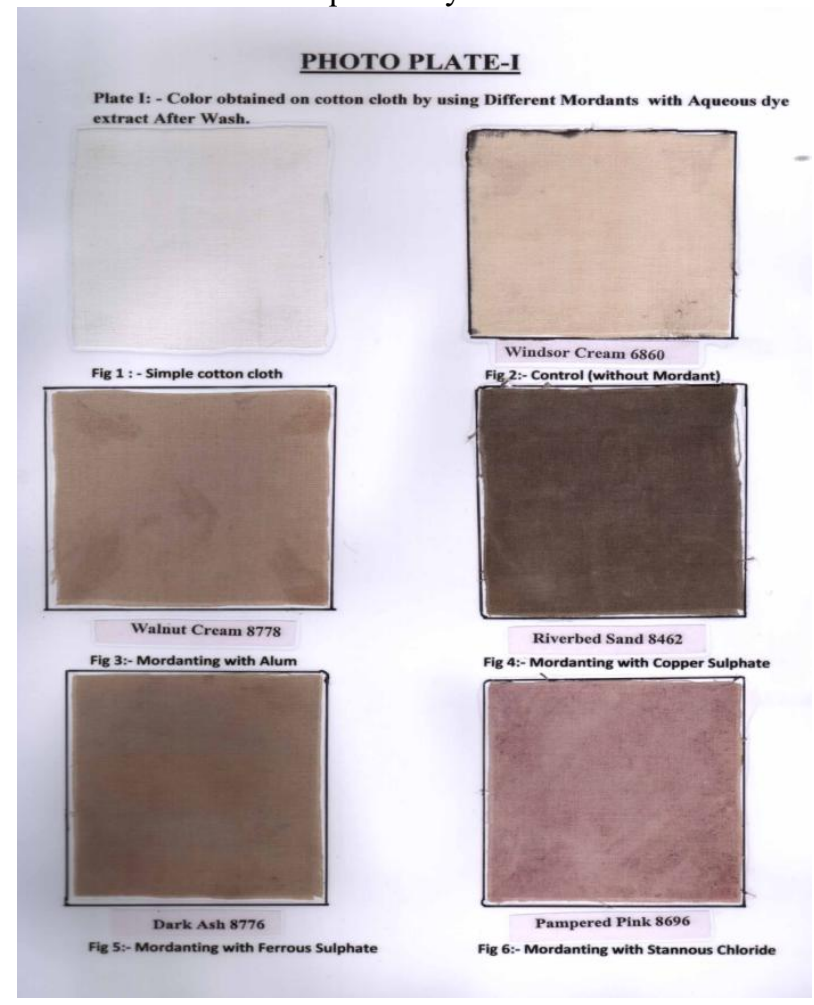

Methanolic extract of Ixora coccinea (Linn.) extracted more pigments as compared to aqueous. Methanol control exhibits bright and light shadeRose petal 0208 that is matched with Sparrow feather 8659, Quarry stone 8658, Digital grey 8312 and Dash of purple 7160 were obtained in Alum (5\%), Copper sulphate $(2 \%)$ Ferrous sulphate $(2 \%)$ and Stannous chloride (2\%) respectively (Photo Plate $-\mathrm{II})$. Significant variations were obtained in this group; Alum (2\%) and Copper sulphate (2\%) generated light shades i.e.Sparrow feather 8659 and Quarry stone 8658 respectively whereas, $2 \%$ Ferrous sulphate and Stannous Chloride generated unique and dark shades to cotton fabric exhibitsDigital grey 8312 in Ferrous sulphate and Dash of purple 7160 in Stannous chloride. Comparatively Ferrous sulphate (Digital grey 8312) and Stannous Chloride (Dash of purple 7160) of methanolic extracts and copper sulphate (Riverbed sand 8462) of aqueous extracts fixes color to the fabric more deeply as compared to the rest of the mordants in both aqueous as well as methanolic extracts.Sample dyed with Ixora dye exract by using the mordants exhibits good light wash fastness (Photoplate I and II). Wash fastness of the dye is influenced by the rate of diffusion of dye and state of dye as well as tendency to aggregate inside the fibre. Methanolic extracts generated unique shades in all mordants. Thus various light and brighter shades were obtained by using different mordants on cotton fabric. Ferrous sulphate and Copper Sulphate have the ability of forming co-ordination complexes [6]. Good light fastness by using copper sulphate and ferrous sulphate as a mordants due to strong co-ordination tendency of $\mathrm{Fe}$ enhances the interactions between the fiber and the dye, resulting in high dye uptake as well as protects the chromophore from photolytic degradation [4]. The use of copper or ferrous sulphate gives high resistance to fading, whereas stannous chloride or alum does not. Both aqueous and methanol extracts generated unique shades in all mordants. Natural dyes have better biodegradability and generally have higher compatibility with the environment. They are non-toxic, nonallergic to skin, non-carcinogenic, easily available and renewable [6].

Plate 1: Color obtained on cotton cloth by using Different Mordants with Methanol dye extract after wash 


\section{International Journal of Science and Research (IJSR) \\ ISSN (Online): 2319-7064}

Index Copernicus Value (2013): 6.14 | Impact Factor (2014): 5.611

\section{PHOTO PLATE-II}

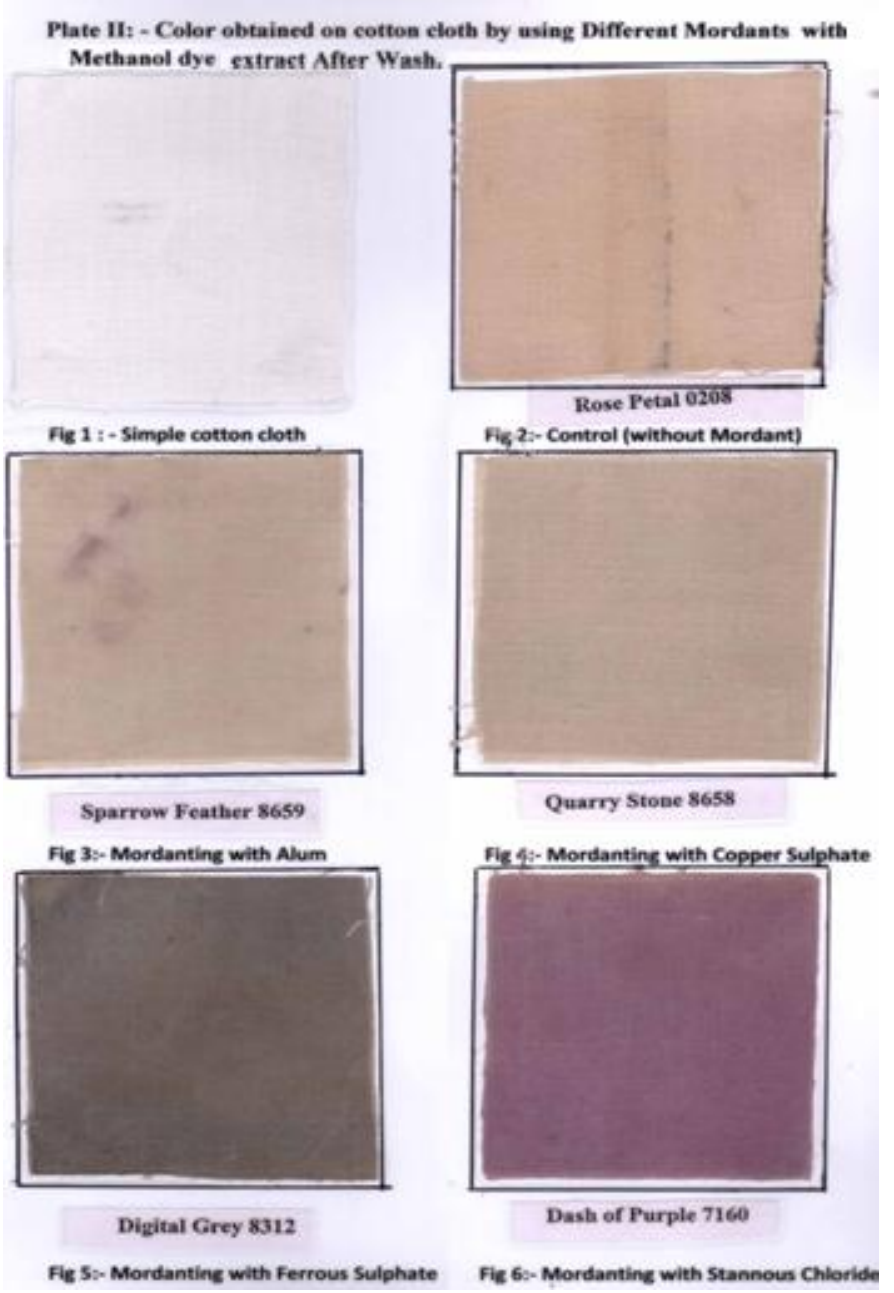

The Analysis of UV- VIS Spectroscopy:

The Pigments obtained from UV-VIS spectrum of Ixoracoccinea (Linn.) flowers extracted in distilled water and methanol is shown in Table I with absorption at $190 \mathrm{~nm}$ to $1100 \mathrm{~nm}$. Absorption spectrum shown in Table I indicated that after an addition of different mordants in aqueous extracted dye, the organic pigments showed polarity towards the cotton fabric.UV analysis of the dye extract gives, Absorption at maximum wavelength for aqueous dye extract at $525 \mathrm{~nm}$ for anthocyanins, $535 \mathrm{~nm}$ for cyanidin, $538 \mathrm{~nm}$ for betalains, 430 $\mathrm{nm}$ for chl a, chl b at $450 \mathrm{~nm}, 500 \mathrm{~nm}$ for carotenoids, $475 \mathrm{~nm}$ for xanthophyll, $618 \mathrm{~nm}$ for phycocyanin and $576 \mathrm{~nm}$ for phycoerythrin. The red/pink color was obtained with interaction of anthocyanins, betalains and carotenoids at $520 \mathrm{~nm}, 538 \mathrm{~nm}$ and $500 \mathrm{~nm}$. With addition of mordent alum $2 \%$ the polarity of bonds increases and attachment organic compound firmly to the chromophore loosely or tightly according to formation of bonding is complex structure (Table 1). After addition of alum to extracted aqueous flower extracted dyes anthocyanin peak at $520 \mathrm{~nm}$, cyanidin at $535 \mathrm{~nm}$, betalins at $538 \mathrm{~nm}$, Chloa at $430 \mathrm{~nm}$, Chlo b at $642 \mathrm{~nm}$,carotenoids at $500 \mathrm{~nm}$, xanthophylls at $475 \mathrm{~nm}$, phycocyanin at $623 \mathrm{~nm}$ while phycoerythrin peak at $490 \mathrm{~nm}$.

Table 1: UV-Vis absorption spectrum of Aqueous and Methanol extracted dye pigments and its interaction with Different

Mordents from Ixora coccinea (Linn.) flowers (Red).

\begin{tabular}{|c|c|c|c|c|c|c|c|c|c|c|}
\hline Pigments & $\begin{array}{c}\text { Aqueous } \\
\text { extracted } \\
\text { dyes } \\
\text { without } \\
\text { mordant } \\
(\mathrm{nm})\end{array}$ & $\begin{array}{c}\text { Aqueous } \\
\text { extracted } \\
\text { dye }+ \\
5 \% \text { Alum } \\
(\mathrm{nm})\end{array}$ & $\begin{array}{c}\text { Aqueous } \\
\text { extracted } \\
\text { dyes+ } \\
2 \% \\
\text { Copper } \\
\text { sulphate } \\
(\mathrm{nm})\end{array}$ & $\begin{array}{c}\text { Aqueous } \\
\text { extracted } \\
\text { dye }+2 \% \\
\text { Ferrous } \\
\text { sulphate } \\
(\mathrm{nm})\end{array}$ & $\begin{array}{c}\text { Aqueous } \\
\text { extracted } \\
\text { dye }+2 \% \\
\text { Stannous } \\
\text { Chloride } \\
(\mathrm{nm})\end{array}$ & $\begin{array}{c}\text { Methanol } \\
\text { extracted } \\
\text { dye } \\
\text { without } \\
\text { mordant } \\
(\mathrm{nm})\end{array}$ & $\begin{array}{c}\text { Methanol } \\
\text { extracted } \\
\text { dye }+ \\
5 \%\end{array}$ & $\begin{array}{c}\text { Methanol } \\
\text { extracted } \\
\text { dye }+ \\
\% \\
\text { Alum } \\
(\mathrm{nm})\end{array}$ & $\begin{array}{c}\text { Methanol } \\
\text { extracted } \\
\text { Copper } \\
\text { dye }+\% \\
\text { sulphate } \\
(\mathrm{nm})\end{array}$ & $\begin{array}{c}\text { Methanol } \\
\text { Ferrous } \\
\text { sulphate } \\
\text { (nm) }\end{array}$ \\
$\begin{array}{c}\text { dye }+\% \\
\text { Stannous } \\
\text { Chloride } \\
(\mathrm{nm})\end{array}$ \\
\hline Anthocyanins & 525 & 520 & 526 & 520 & 527 & 518 & 520 & 520 & 521 & 524 \\
\hline Cyanidin & 535 & 535 & 535 & 535 & 535 & 535 & 535 & 535 & 535 & 535 \\
\hline Betalains & 538 & 538 & 538 & 538 & 538 & 476 & 538 & 538 & 538 & 538 \\
\hline Chl a & 430 & 430 & 430 & 430 & 430 & 430 & 430 & 430 & 436 & 436 \\
\hline Chl b & 450 & 642 & 640 & 640 & 458 & 640 & 454 & 450 & 640 & 458 \\
\hline Carotenoids & 500 & 500 & 500 & 400 & 400 & 500 & 400 & 500 & 500 & 400 \\
\hline Xanthophyll & 475 & 475 & 450 & 475 & 475 & 475 & 445 & 445 & 475 & 425 \\
\hline Phycocyanin & 618 & 623 & 618 & 620 & 623 & 618 & 626 & 618 & 618 & 618 \\
\hline Phycoerythrin & 576 & 490 & 576 & 576 & 576 & 576 & 490 & 576 & 490 & 490 \\
\hline
\end{tabular}




\section{International Journal of Science and Research (IJSR) \\ ISSN (Online): 2319-7064 \\ Index Copernicus Value (2013): 6.14 | Impact Factor (2014): 5.611}

Each mordent produced unique and dark shades to the cotton fabric, might be due to the interaction of chl a and chl b with the other red colored pigment which helps to fix the color more to the fabric (Photo plate- I) With the addition of alum and other different mordents in methanolic extracted dye, the organic pigments mainly carotenoids, xanthophylls, anthocyanin, betalains and phycoerythrin showed polarity which owes unique shades to the cotton fabric while the mordants like ferrous sulphate and stannous chloride generated dark and bright shades to the cotton fabric as compared to other mordents that might be due to the interaction of chl a and chl b with the other red colored pigment which increases polarity of bonds that helps to fix the color more deep to the fabric (Photo plate- II) . The dye absorption for the dyes extracted from Mimusop selengi and Terminalia arjuna showed that depending on the concentrations of dyes in the dye bath, the dye absorbed on the fiber varies from $21.94 \%$ to $27.46 \%$ and from $5.18 \%$ to $10.78 \%$ respectively [2]. The color components isolated from most of the barks contain flavonoid moiety.

\section{Conclusion}

The present study revealed the dyeing potential of Ixora coccinea (Linn.) flowers as a source for cotton dyeing. The whole process of extraction and dyeing is ecologically safe.Different shades of color were obtained by using different chemical mordants in both the solvent systems. Good light and washing fastness exhibited by the dyed cloth is because of the mordants used. Both the solvent extracts exhibits unique shades and affix it deeply to the cotton fabric.Spectral analysis showed different binding affinity with different chromophore groups within the pigments which can acts as chelating agents affix to the fabric and gives different shades to the fabric. Ixora dye has good scope in the commercial dyeing of textiles.

\section{References}

[1] Bhattacharya, "Review article Application of natural dyes on textiles," Indian J. Fabric and textile Research, 34, pp. 384-399, 1999.

[2] R. Bhuyan and C. N. Saikia, "Isolation of colour components from native dye-yielding plants in Northeastern India," Biores. Technol, 96 (3):pp. 63-72, 2005.

[3] B. Ghorpade, M. Darvekar, and P.S.Vankar, "Eco-friendly cotton dyeing with Sappan wood dye using ultrasound energy," Colourage , pp.27-30, 2000.

[4] D. Jothi, "Extration of Natural Dyes from African Marigold Flowers (Tagetus erecta) for Textile Coloration," Autex Research Journal, Vol.89(2): pp.4953, 2008.

[5] M.M. Kamel, H. Helmy, and N. S. Hawary, "Some Studies on Dyeing properties of cotton fabrics with Crocus sativus (Saffron) flowers using an ultrasonic method," Autex Reaserch Journal, 9(1), 2009.

[6] S. S. Kulkarni, A. V. Gokhale, U. M. Bodake, G. R. Pathade, "Cotton Dyeing with Natural Dye Extracted from
Pomegranate (Punica granatum) Peel," Universal journal of Environmental Research and Technology,1(2):pp.135139, 2011.

[7] P. Nilani, B.Duraisamy, P.Dhamodaran, N.Kasturibai, Alok ,Samwol, and B. Suresh," A study on the effect of Marigold Flower dye with natural mordant on selected fibers,"Journal of Pharmacy Research,1(2): pp.175-181, 2008.

[8] M.C. Purohit and ShyamVir Singh, "Applications of EcoFriendly Natural Dye on Wool Fibers using Combination of Natural and Chemical Mordants," Universal Journal of Environmental Research and Technology, 2(2): pp.48-55, 2012.

[9] Rakhi, Shankar, and S.V. Padma, "Dyeing Cotton, Wool and Silk with Hibiscus mutabilis (Gulzuba) Dyes and Pigments," Elsevier, pp.1-6, 2006.

[10]D.V. Rangari, Natural colorants and dye In: Phrmacognosy and Phytochemistry (Part II), Ed. $1^{\text {st. }}$. Career publication, pp. 98-117,2004.

[11] K.Sachan, and V.P.Kapoor, "Optimization of Extraction and Dyeing conditions for Traditional Turmeric Dye," IJTK, 6(2): pp.270-278, 2007.

[12] A.K. Samanta, and P. Agrawal, "Application of Natural Dyes on Textiles," Indian Journal of Fibre and Textile Research,34: pp.384-399, 2009.

[13] R. Siva, "Status of Natural Dyes and Dye yielding Plants in India, "Current Science, 92(7): pp.916-924, 2007.

[14] The Wealth of India, Raw Materials, Volume J. 2003.

[15] P.S.Vankar, R.Shankar, and S.Vijaypala, "Dyeing Cotton, Silk and Wool Yarn with Extract of Garniciamangostana Pericarp,"JTATM, 6(1): 2009.

[16] R. Siva, "Status of Natural Dyes and Dye yielding Plants in India, "Current Science, 92(7): pp.916-924, 2007.

[17] The Wealth of India, Raw Materials, Volume J. 2003.

[18] P.S.Vankar, R.Shankar, and S.Vijaypala, "Dyeing Cotton, Silk and Wool Yarn with Extract of Garniciamangostana Pericarp,"JTATM, 6(1): 2009.

\section{Author Profile}

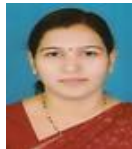

Monali Ghurde received the B.S. degrees in Biology, Brijlal Biyani Science College, Amravati (Maharashtra) in 2000 and M.S. degree in Botany at GVISH, Amravati (M.S.) in 2002. Research area of interests are Cytogenetics, Mycology and Molecular biology. 